\title{
Kajian Bangunan Penangkap Kabut Dan Penampung Air Hujan Untuk Daerah Sentul Sebagai Ganti Air Bersih
}

\author{
Christine D.M.D. Kowaas ${ }^{1}$, Fachrian Kanafani ${ }^{1}$, Fariz Adya Fathaya ${ }^{1}$, Muhammad Irfan ${ }^{1}$, \\ Vania A. Pratiwi ${ }^{1}$, Rizka Arbaningrum ${ }^{2}$ \\ ${ }^{1}$ Program Studi Teknik Sipil, Universitas Pembangunan Jaya \\ ${ }^{2}$ Center for Urban Studies, Universitas Pembangunan Jaya \\ rizka.arbaningrum@upj.ac.id
}

\begin{abstract}
Drought is very detrimental to farmers because it affects their crops. There are two ways to overcome the problem of drought, namely by building fog harvesting building or by building rain water storage structures. However, which of the two buildings is superior for use is seen from economic factors and durability. If compared from the price, fog harvesting needs low cost than rain water harvesting. Fog harvesting building costs Rp. 685.000,-. To accommodate 300 liters of water, rain water harvesting building costs Rp. 1.431.466,-. When compared to fog harvesting building, rain water harvesting are more costly. For durability, fog harvesting building tends to need more special care because the materials and tools used are very simple. Meanwhile, rain water harvesting buildings tends to be more durable even though it still requires maintenance for reservoirs and water pumps.
\end{abstract}

Keywords : Drought, fog harvesting, rain water harvesting

\begin{abstract}
Abstrak : Kekeringan merugikan petani karena mempengaruhi hasil panen. Terdapat dua cara untuk mengatasi masalah kekeringan yaitu dengan cara membuat bangunan penangkap kabut atau juga bisa dengan membuat bangunan penampung air hujan. Namun, dari kedua bangunan itu manakah yang lebih unggul untuk digunakan dilihat dari faktor ekonomi dan durabilitas. Ditinjau dari harga, penangkap kabut tidak membutuhkan biaya yang tinggi bila dibandingkan dengan penampung air hujan. Pembuatan penangkap kabut membutuhkan biaya Rp 685,000,- sedangkan penampung air hujan membutuhkan biaya Rp 1.431.466,. Apabila dibandingkan dengan bangunan penangkap kabut, penampung air hujan membutuhkan biaya yang lebih tinggi. Untuk durabilitas bangunan, penangkap kabut cenderung lebih perlu perawatan khusus dikarenakan bahan dan alat yang digunakan sangat sederhana. Sedangkan, bangunan penampung air hujan, durabilitas cenderung bertahan lama meskipun tetap membutuhkan perawatan untuk bak penampung dan pompa air.
\end{abstract}

Kata Kunci : Kekeringan, penampung air hujan, penangkap kabut, biaya

\section{PENDAHULUAN}

\section{Latar Belakang}

Indonesia memiliki dua musim, yaitu musim hujan dan musim kemarau. Pada musim kemarau, akan cenderung sulit untuk mendapatkan air bersih. Air bersih lebih baik digunakan untuk memenuhi kebutuhan sehari-hari daripada digunakan untuk menyiram tanaman.
Menyiram tanaman dapat menggunakan air hujan atau air kotor yang diperoleh dari air hujan maupun kabut, dengan pengelolaan lebih lanjut agar dapat dimanfaatkan.

Global warming yang terjadi saat ini, berdampak pada periode pergantian musim hujan dan musim kemarau tidak menentu. Musim kemarau menyebabkan 
kekeringan pada beberapa wilayah di Indonesia. Kekeringan ini mengakibatkan banyaknya petani yang mengalami gagal panen dikarenakan tidak tercukupinya air untuk tanaman yang ditanamnya.

Daerah Sentul merupakan daerah dataran tinggi yang mata pencaharian warga rata-rata adalah berkebun. Dengan mata pencaharian berkebun, diperlukan air untuk menyiram tanaman. Kelangkaan terhadap air bersih membuat para warga yang tinggal di daerah dataran tinggi mencari cara untuk mengganti air bersih agar dapat digunakan untuk menyiram tanaman.

Dari sumber masalah di atas, kawasan Sentul memiliki potensi kabut yang cukup besar. Karena Sentul merupakan daerah dataran tinggi dan asri, sehingga suhu rata rata di daerah tersebut memungkinkan untuk terciptanya kabut ketika malam atau pagi hari. Dari kondisi kekeringan dan potensi kabut yang cukup besar seperti yang sudah banyak kita ketahui bangunan penangkap kabut adalah solusi yang pas bagi permasalahan di daerah tersebut.

Kelangkaan air pada dataran tinggi dan pada saat musim kemarau serta potensi kabut pada wilayah Sentul yang dapat dimanfaatkan, mendorong penulis untuk membuat kajian bangunan penangkap kabut dan penampung air hujan sebagai solusi cara mendapatkan air hujan yang dapat bermanfaat untuk menyiram tanaman sebagai pengganti air bersih sehingga air bersih dapat digunakan untuk kebutuhan sehari-hari lainnya.

\section{Formulasi Masalah}

Perubahan iklim yang sudah tidak dapat diprediksi, menyebabkan cuaca tidak menentu, seperti curah hujan dengan intensitas yang tinggi berpotensi mengakibatkan banjir dan ketika musim kemarau datang mengakibatkan kekeringan.

Kabut yang terjadi akibat proses alam mendorong penulis mengkaji hal tersebut agar dapat dimanfaatkan dan digunakan ketika musim kemarau tiba.

\section{Tujuan}

Mengetahui efisiensi dari bangunan penangkap kabut atau bangunan penampung air hujan yang dapat dimanfaatkan untuk mengatasi masalah yang telah dijelaskan di atas.

\section{KAJIAN PUSTAKA}

Air

Air adalah zat cair yang tidak mempunyai rasa, bau dan warna dan terdiri dari hidrogen dan oksigen, sehingga gapat dirumuskan menjadi $\mathrm{H}_{2} \mathrm{O}$.

Air bersih adalah air baku layak pakai yang digunakan untuk memenuhi kebutuhan sehari-hari manusia. Air bersih berasal dari mata air, air tanah, dan aliran air permukaan.

Air kotor adalah air yang telah digunakan, biasanya bersumber dari air buangan kamar mandi, WC, dapur, dan tempat cuci rumah tangga maupun skala kantoran. Air hujan tidak termasuk dalam air kotor.

Air domestik adalaha air yang biasa digunakan untuk keperluan rumah tangga dalam hal ini untuk minum, memasak masakan, dan mandi. Kebutuhan air domestik ini sangat ditentukan dari jumlah penduduk dan konsumsi perkapita. Selain itu air non domestik juga sangat dibutuhkan untuk pemanfaatan komersial, institusi dan industri.

Air berasal dari aliran air. Aliran air adalah sumber air yang keluar secara alami ke permukaan dari dalam tanah. Sumber dari aliran air adalah air tanah yang mengalami patahan sehingga muncul ke permukaan (Arthana, 2007).

Ketersediaan air wilayah dipenuhi dari beberapa sumber air yang ada di bumi. Keberadaan sumber air diperlukan untuk keberlangsungan manusia, hewan, dan tumbuhan dalam mempertahankan hidup (Sumarman, 2006). Sedangkan menurut Undang Undang Sumber Daya Air No.7 Tahun 2004 adalah tempat atau wadah air alami atau buatan yang terdapat 
dibeberapa bagian permukaan tanah, termasuk dalam pengertian ini air tanah, air hujan, dan air laut yang berada di darat. Keberadaan air di suatu tempat yang berbeda, membuat air dapat berlebih apabila tidak dimanfaatkan dan dapat kekurangan apabila penggunaannya tidak dikelola dengan baik. Pengelolaan air diperlukan untuk pengontrolan agar air dimanfaatkan efisien sesuai dengan kebutuhan masing-masing rumah. (Robert J. Kodoatie, 2008).

\section{Kekeringan}

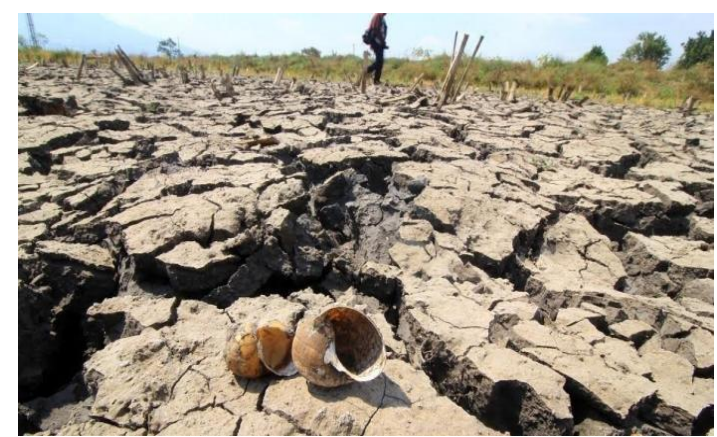

Gambar 1. Kondisi saat Kekeringan Sumber: Tribunnews.com

Kekeringan adalah keadaan kekurangan air pada suatu daerah dalam jangka waktu yang lama (beberapa bulan hingga bertahun-tahun). Perubahan tingkat ketersedian air wilayah akan terlihat jelas pada saat memasuki musim kemarau. Hal ini disebabkan karena tingkat presipitasi pada bulan kering itu wilayah mengalami penurunan, sehingga air yang tersimpan di dalam tanah akan berkurang. Penurunan kapasitas air tersimpan disebabkan oleh evapotranspirasi dan tingkat drainase disuatu wilayah.

Menurut Irianto (2005) secara faktual kekeringan lebih menakutkan jika dibandingkan dengan banjir dalam hal besaran: luas wilayah, durasi kejadian, biaya dan pemulihan. Namun, sering kita jumpai penanggulangan kekeringan ini belum dilaksanakan dengan baik dikarenakan kurangnya data dan informasi pada wilayah wilayah endemik kekeringan.
Kekeringan terjadi pada musim kemarau. Menurut BMKG, pada data 2018, musim kemarau terjadi pada Februari hingga Agustus. Pada rentang bulan tersebut, tingkat keparahan kekeringan dipetakan oleh BMKG menurut data 2018, terlihat pada Gambar 2.

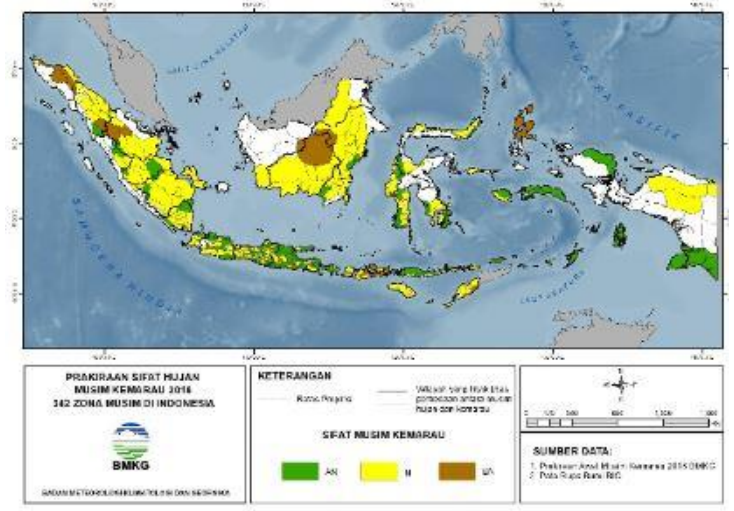

Gambar 2. Pemetaan Tingkat Keparahan Kekeringan di Indonesia Sumber: BMKG 2018

Tingkat keparahan pada Gambar 2, terdiri dari hijau, kuning, dan cokelat. Hijau menandakan bahwa tingkat kekeringan tidak parah atau musim kemarau tidak berdampak pada daerah tersebut, warna kuning menandakan bahwa daerah tersebut terkena dampak kekeringan yang tidak dikategorikan parah, serta warna cokelat menandakan bahwa daerah tersebut mengalami kekeringan dengan tingkat parah.

Daerah Sentul merupakan suatu wilayah di Provinsi Bogor. Pada pemetaan kekeringan Gambar 2, data menunjukkan bahwa kekeringan yang terjadi pada daerah Sentul memberikan dampak yang tidak tergolong parah, namun perlu diwaspadai agar tidak menjadi lebih parah. Oleh sebab itu, pemakaian air bersih perlu dikelola agar tidak menimbulkan dampak yang parah.

\section{Kabut}

Kabut dapat terbentuk saat udara yang jenuh akan uap air didinginkan dibawah titik bekunya. Maka dari itu, daerah dataran tinggi yang memiliki suhu dingin dan lembab masih sering kita jumpai kabut. Daerah Sentul merupakan Kawasan 
dataran tinggi, sehingga kawasan ini masih sering dijumpai kabut. Jenis kabut pegunungan terbentuk ketika uap air bergerak menuju ke atas melewati lerenglereng gunung, udara dingin bergerak ke atas lereng hingga tidak sanggup menahan uap air, titik-titik kabut kemudian terbentuk disepanjang lereng gunung.

\section{Bangunan Penangkap Kabut}

Fog harvesting merupakan teknologi inovatif yang didasarkan pada pengumpulan air yang dikumpulkan dari kabut dalam kondisi iklim tertentu. Kabut merupakan uap air yang berada dekat permukaan tanah berkondensasi dan menjadi mirip awan. Hal ini biasanya terbentuk karena hawa dingin membuat uap air berkondensasi dan kadar kelembaban mendekati $100 \%$ (Soto Alvarez, 1992).

Perbedaannya, awan tidak menyentuh permukaan bumi sedangkan kabut menyentuh permukaan bumi, oleh sebab itu terciptalah inovasi pemanfaatan kabut dalam ide yakni bangunan penangkap kabut. Komponen-komponen bangunan penangkap kabut terdiri dari, sebagai berikut:

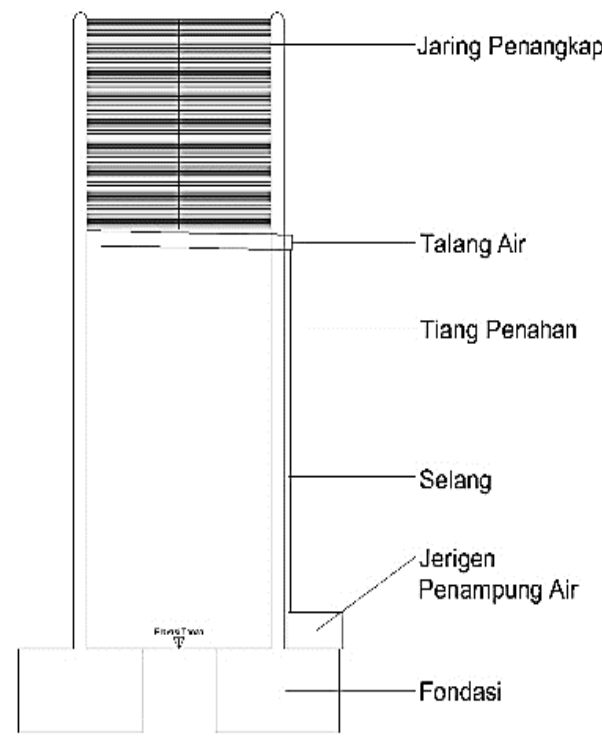

Gambar 3. Perancangan Bangunan Penangkap Kabut

Menurut (Marzol, 2008) berdasarkan schemenauerand Cereceda Standar Fog
Collector (SFC), desain model (1994) ukuran standar penelitian alat penangkap kabut adalah $1 \mathrm{~m}^{2}$, yang terbagi menjadi 4 jaring sama sisi.

Alat dipasang dengan ketinggian $\pm 3 \mathrm{~m}$ dari atas tanah, dan posisinya tegak lurus dengan tanah agar kabut dapat terbawa oleh angin yang kemudian proses tangkapannya lebih baik.

Untuk bagian bawah tiang penahan jaring kabut menggunakan fondasi dangkal guna memperkuat agar jaring tidak mudah roboh ketika di terpa angin, ukurannya diperkirakan memiliki kedalaman $\pm 35 \mathrm{~cm}$ dan lebar $\pm 50 \mathrm{~cm}^{2}$ fondasi ini menggunakan beton. Pada bagian jaringnya, jaring dipasang satu lapis. Bagian bawah jaring yang menempel dengan frame jaring dipasang talang air atau setengah paralon besar dengan ukuran untuk talang air berkisar $1 \times 0.15 \times 0.15 \mathrm{~m}$ yang kemudian pada bagian ujungujungnya diberikan penutup agar air tidak keluar dari talang atau setengah paralon, untuk ukuran setengah paralon dapat di sesuaikan, pada bagian penutupnya diberikan lubang konektor ke selang yang akan tersambung di jerigen-jerigen penampung air.

Pembuatan bangunan penangkap kabut memberikan manfaat, antara lain:

1. Membantu warga sekitar memenuhi suplai air untuk menyiram tanaman pada saat musim kemarau dan kondisi kekeringan yang melanda wilayah mereka. Para petani pun tidak perlu khawatir lagi akan datang nya musim paceklik, karena alat ini akan sangat membantu petani mendapatkan air yang dapat mereka gunakan untuk lahan persawahan mereka.

2. Air yang dihasilkan dari penangkap kabut dapat diolah sehingga dapat dimanfaatkan menjadi air baku

3. Air bersih yang tersedia dapat digunakan untuk keperluan seharisehari lainnya sehingga jumlah ketersediaan air bersih tidak 
berkurang akibat pemakaian menyiram tanaman

4. Menaikkan hasil panen karena masalah ketersediaan air pada musim kemarau dapat teratasi

5. Menjadi solusi untuk menangani permasalahan air yang terjadi pada musim kemarau pada daerah Sentul

\section{Bangunan Penampung Air Hujan}

Penampung air hujan atau disingkat dengan PAH adalah wadah yang berfungsi untuk menampung air hujan, sehingga air hujan yang telah ditampung dapat digunakan untuk menyiram tanaman apabila tidak dirancang tanpa proses filtrasi sederhana (Pangestu, 2014).

Air hujan tidak layak dikonsumsi untuk memenuhi kebutuhan sehari-hari apabila tidak melalui proses filtrasi sederhana. Maka, pemanfaatan air hujan hanya dapat digunakan sebatas untuk menyiram tanaman, apabila air hujan tidak diolah untuk menjadi air baku.

PAH didesain sedemikian rupa untuk mengalirkan air hujan yang turun melalui atap rumah agar masuk ke dalam PAH yang telah dibuat melalui pipa-pipa yang dipasang. Komponen-komponen PAH, antara lain:

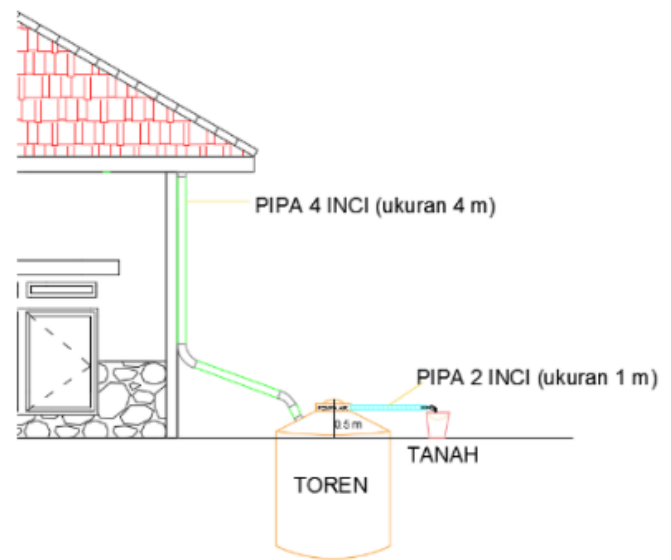

Gambar 4. Perancangan Bangunan Penampung Air Hujan

\section{Pipa Pemasukan Air dari Talang}

Atap sebagai media bantuan untuk mengalirkan air hujan yang turun, yang kemudian dialirkan melalui talang atau pipa untuk menuju bangunan PAH. Kemudian air hujan yang melewati talang atau pipa ditampung pada bak penampung air hujan.

2. Bak Penampungan Air (Toren)

Kapasitas bak penampung air muat menampung sebanyak 300 liter. Bak ini diletakkan di dalam tanah dan bagian kepalanya berada di atas tanah dengan ketinggian setengah meter di atas permukaan tanah. Bak ini menampung air hujan yang sudah melewati talang dan pipa kemudian disimpan dan dialirkan kembali dengan dibantu Pompa Air.

\section{Pompa Air}

Pompa air ini berfungsi untuk membantu mengeluarkan air melalui keran yang kemudian dialirkan pada bak penampungan air. Pompa air diletakkan pada lubang yang terletak di bagian atas bak penampung air (toren).

\section{Wadah Pengambilan Air}

Wadah ini akan berfungsi sebagai pengambilan air dari Bak penampung air melalui keran yang kemudian bisa langsung digunakan baik menggunakan wadah ataupun selang untuk menyiram tanaman atau lain sebagainya.

Pembuatan penampung air hujan menjadi daya tarik tersendiri yang ditawarkan sistem ini untuk mengatasi krisis air bersih di perkotaan maupun pedesaan terutama di saat musim kemarau berlangsung. Selain itu, bahan yang digunakan mudah ditemukan sehingga tidak menjadi kendala dalam pembuatan penampung air hujan. Namun, untuk skala besar, pembuatan penampung air hujan di perkotaan pada pemukiman, memerlukan ketersediaan lahan yang luas, sehingga menjadi kendala untuk pembuatan $\mathrm{PAH}$.

Pembuatan bangunan penampung air hujan memberikan manfaat, antara lain:

1. Mengatasi permasalahn fluktuatif antara kekurangan air dan kelebihan air di kawasan Sentul 
2. Mengurangi penggunaan air tanah, sehingga ketersediaan air tanah tidak kian berkurang

3. Pada suatu kondisi, air hujan dapat mempunyai status ekonomis yang lebih besar yaitu dapat difungsikan untuk kebutuhan sehari-hari seperti menyiraman tanaman, mencuci kendaraan, bahkan untuk pengisian bak dikamar mandi pada bangunan fasilitas umum seperti rumah toko, apartemen, dan gedung-gedung bertingkat.

4. Dapat menjadi solusi untuk mengatasi kelebihan air agar air tidak menggenang ke area yang mempunyi elevasi yang lebih rendah

5. Apabila setiap rumah pada daerah dataran tinggi mempunyai bangunan penampung air hujan, maka dapat mencegah terjadinya kondisi tanah jenuh agar tanah tidak longsor. Mengurangi runoff dan beban sungai saat hujan lebat

\section{Metodologi Penelitian}

Metodologi penelitian yang digunakan adalah studi pustaka, yaitu serangkaian kegiatan yang berkenaan dengan metode pengumpulan data pustaka. Menurut Nyoman Kutha Ratna dalam Prastowo (2012: 80), kajian pustaka adalah seluruh bahan bacaan yang mungkin pernah dibaca dan dianalisis, baik yang sudah dipublikasikan maupun sebagai koleksi pribadi.

\section{Hasil Penelitian dan Analisis}

\section{A. Analisis}

\section{Bangunan Penangkap Kabut}

Proses-proses untuk mendapatkan air dari hasil kabut dengan bangunan penangkap kabut yang terbuat dari jaring-jaring, yaitu:

\section{a) Pengumpulan air kabut}

Menggunakan jaring saringan dari polipropilen di gundukan tanah untuk menangkap kabut yang sarat air, yang terbentuk pada bulan-bulan lembab di daerah pegunungan atau pesisir. Saringan ini didirikan tegak lurus terhadap angin yang bertiup. Saringan menangkap tetesan air kecil $(1-40 \mu \mathrm{m})$, yang mengalir perlahan ke talang pengumpul atau parit dan selokan menuju serangkaian tangki. Pepohonan dan rumput menghadang kabut dengan cara yang sama.

Kabut yang terhadang umumnya memiliki kualitas baik, namun dapat dipengaruhi polusi udara, debu di atap atau karat di lembaran logam. Jika berbagai langkah dilakukan untuk mencegah aliran air pertama yang tercemar memasuki tangki penyimpanan, maka airnya layak untuk diminum dan digunakan untuk keperluan rumah tangga lainnya dengan sedikit atau tanpa penanganan lainnya.

\section{b) Kondisi yang Sesuai}

Pengumpulan kabut paling sesuai untuk lokasi yang sering mengalami periode kabut. Daerah dataran tinggi tempat kabut dihasilkan oleh adveksi awan di atas tanah atau tempat awan dipaksa menaiki gunung adalah tempat yang paling cocok, di daerah yang kecepatan anginnya antara 3-12 meter/detik dan tidak ada rintangan terhadap aliran angin. Kabut terbentuk di permukaan samudra, atau kabut radiasi panas malam di dataran rendah yang biasanya tidak memiliki kandungan air dalam bentuk cair yang cukup atau kecepatan angin yang mencukupi untuk pengumpulan air yang memadai.

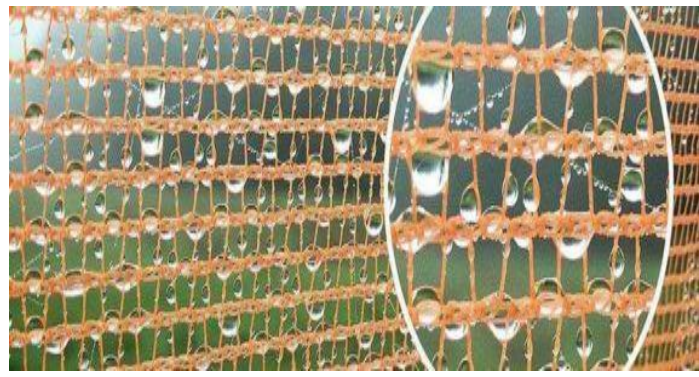


Gambar 5. Jaring-jaring Penangkap Kabut

c) Rincian biaya pembuatan bangunan penangkap kabut

\begin{tabular}{|c|c|c|c|c|c|}
\hline No & Nama & satuan & jumlah & Harga & Total \\
\hline 1 & Jaring Polypropylene & $\mathrm{m}^{2}$ & 1,5 & Rp30.000 & Rp45.000 \\
\hline 2 & Besi hollow $1.5^{\prime \prime}$ & $M$ & 1 & $\mathrm{Rp} 40.000$ & $\mathrm{Rp} 40.000$ \\
\hline 3 & Talang $\mathrm{u}$ & $M$ & 1 & Rp10.000 & Rp10.000 \\
\hline 4 & Jerigen 251 & Unit & 1 & $\operatorname{Rp} 30.000$ & $\mathrm{Rp} 30.000$ \\
\hline 5 & Pipa PVC 2" & $M$ & 4 & Rp3.500 & Rp14.000 \\
\hline 6 & Penutup talang & Unit & 2 & Rp5.000 & Rp10.000 \\
\hline 7 & Pipa L & Unit & 1 & Rp4.000 & Rp4.000 \\
\hline 8 & Kawat & $\mathrm{Kg}$ & 1 & $\operatorname{Rp} 25.000$ & Rp25.000 \\
\hline 9 & Besi tulangan & $M$ & 6 & Rp3.000 & Rp18.000 \\
\hline 10 & Semen & Sak & 1 & Rp65.000 & Rp65.000 \\
\hline 11 & Agregat kasar & $\mathrm{m}^{3}$ & 0,25 & Rp65.000 & Rp65.000 \\
\hline 12 & Bambu & $\mathrm{m}$ & 7 & Rp7.000 & Rp49.000 \\
\hline 13 & Alat pencatat & Set & 1 & Rp10.000 & Rp10.000 \\
\hline 14 & Penerangan & Set & 1 & Rp50.000 & Rp50.000 \\
\hline 15 & Pagar & $\mathrm{M}$ & 10 & $\mathrm{Rp} 5.000$ & $\mathrm{Rp} 50.000$ \\
\hline 16 & Perawatan bulanan & Bulan & 4 & $\operatorname{Rp} 50.000$ & Rp200.000 \\
\hline \multicolumn{5}{|c|}{ Total } & Rp685.000 \\
\hline
\end{tabular}

Gambar 6. List Harga yang dibutuhkan untuk 1 unit penangkap kabut

Dalam membuat bangunan penangkap kabut dengan menggunakan jaring-jaring sebagai media kabut untuk mengalir, besi hollow 1.5", agregat kasar, kawat, bambu, pipa L, pipa PVC 2", semen 1 sak, jerigen air untuk menampung air dari kabut, sehingga memerlukan biaya pembuatan bangunan penangkap kabut sebesar $\mathrm{Rp}$ 685.000 .

\section{Bangunan Penampung Air Hujan}

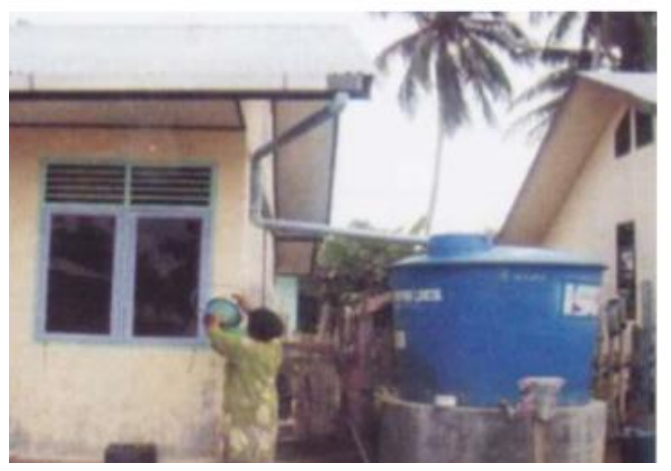

Gambar 7. Bangunan Penampung Air Hujan Sederhana

Sumber: Harsoyo (2010)

Untuk membuat bangunan penangkap kabut secara sederhana, biaya yang diperlukan, terlihat pada Gambar 8.

Bangunan penampung air hujan menggunakan toren dengan kebutuhan tampungan 300 liter air, menggunakan satu pompa sumur dangkal, pipa PVC Wavin 4" tide D, 1 buah pipa PVC Wain 2" tipe AW, 1 box berisi 9 buah sambungan pipa elbow $90^{\circ}$ ukuran 4", dan kawat filter 2 buah. Sehingga, dalam membuat bangunan penampung air hujan, memakan biaya sebesar Rp 1.431.466.

\begin{tabular}{|c|c|c|c|c|}
\hline No. & Keterangan & Gambar & Jumlah & Harga (Rp) \\
\hline 1 & $\begin{array}{c}\text { Bak penampung } \\
\text { merk Penguin } \\
\text { dengan } \\
\text { kapasitas } 300 \\
\text { Liter }\end{array}$ & & 1 buah & 679,970 \\
\hline 2 & $\begin{array}{c}\text { Pompa air } \\
\text { Shimizu PS- } \\
\text { 128BIT pompa } \\
\text { sumur dangkal }\end{array}$ & & 1 buah & 421,996 \\
\hline 3 & $\begin{array}{c}\text { Pipa PVC wavin } \\
4 " \text { tipe D } \\
\end{array}$ & - & 1 buah & 151,200 \\
\hline 4 & \begin{tabular}{|c|} 
Pipa PVC wavin \\
2" tipe AW \\
\end{tabular} & 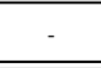 & 1 buah & 86,500 \\
\hline 5 & $\begin{array}{c}\text { Sambungan } \\
\text { Pipa elbow } 90^{\circ} \\
2^{\prime \prime} \\
\end{array}$ & & $\begin{array}{c}1 \text { box ( } 1 \\
\text { box } \\
\text { berisi } 18 \\
\text { buah) } \\
\end{array}$ & 13,000 \\
\hline 6 & $\begin{array}{c}\text { Sambungan } \\
\text { Pipa elbow } 90^{\circ} \\
4^{\prime \prime}\end{array}$ & & $\begin{array}{c}1 \text { box ( } 1 \\
\text { box } \\
\text { berisi } 9 \\
\text { buah) } \\
\end{array}$ & 63,800 \\
\hline 7 & Kawat filter & & 2 buah & 15,000 \\
\hline \multicolumn{4}{|c|}{ Total: } & $\operatorname{Rp~} 1,431,466$ \\
\hline
\end{tabular}

Gambar 8. List Harga yang dibutuhkan untuk 1 unit penampung air hujan

\section{B. Hasil}

Perbandingan efisiensi penangkap kabut dan penampung air hujan:

\section{Bangunan Penangkap Kabut Hujan}

\begin{tabular}{lrl}
\hline Dalam segi & Penampung air hujan \\
konstruksi, penangkap & lebih susah dalam \\
kabut lebih & mudah & segi instalasi. \\
untuk dibuat. & Membutuhkan \\
Penangkap & kabut & keterampilan dalam \\
\multicolumn{2}{l}{ hanya membutuhkan } & pembuatan talang air \\
jaring-jaring yang & dan pemasangan \\
telah dijual di toko & pompa air.
\end{tabular}
bangunan dan jerigen air untuk menampung air.

\begin{tabular}{lrl}
\hline Ditinjau dari harga, & Untuk menampung \\
penangkap kabut tidak & air sebanyak 300 \\
membutuhkan biaya & liter, dibutuhkan \\
yang tinggi $\quad$ bila & biaya Rp $1,431,466$. \\
dibandingkan dengan & Apabila \\
PAH. Pembuatan & dibandingkan dengan \\
penangkap kabut & bangunan penangkap \\
\hline
\end{tabular}




\begin{tabular}{|c|c|}
\hline $\begin{array}{l}\text { membutuhkan biaya } \\
\text { Rp 685.000. }\end{array}$ & $\begin{array}{l}\text { kabut, PAH lebih } \\
\text { membutuhkan biaya } \\
\text { yang lebih tinggi. }\end{array}$ \\
\hline $\begin{array}{l}\text { Durabilitas cenderung } \\
\text { lebih perlu perawatan } \\
\text { khusus dikarenkan } \\
\text { bahan dan alat yang } \\
\text { digunakan sangat } \\
\text { sederhana. }\end{array}$ & $\begin{array}{l}\text { Durabilitas } \\
\text { cenderung lebih awet } \\
\text { meskipun tetap } \\
\text { membutuhkan } \\
\text { perawatan untuk bak } \\
\text { penampung dan } \\
\text { pompa air. }\end{array}$ \\
\hline
\end{tabular}

\section{KESIMPULAN}

Global warming yang terjadi, mendorong petani mencari cara memenuhi kebutuhan air untuk tanaman mereka tanpa membuang-buang air bersih, sehingga dapat disimpulkan bahwa bangunan penangkap kabut merupakan alat yang cocok diterapkan untuk membantu mengatasi masalah kekeringan agar tetap dapat menyirami tanaman tanpa menggunakan air bersih. Air bersih dapat disubstitusi dengan air hasil dari kabut sebagai pengganti untuk menyiram tanaman.

Bila dibandingkan dari segi efektivitas kemudahan konstruksi dan biaya, bangunan penangkap kabut menjadi solusi efektif sebagai alat harversting dalam mengumpulkan air yang dapat disubstitusikan dengan kabut.

\section{DAFTAR PUSTAKA}

1. BPPT. "Pemanen Air Hujan (Rain Water Harvesting)". BPPT.

2. Fatimah, Soja Siti. "Jurnal Pendidikan Kimia, Air". Universitas Pendidikan Indonesia: Bandung.

3. Pemerintah Provinsi DKI Jakarta. (2012). "Panduan Pengguna Bangunan Gedung Hijau Jakarta Vol. 5 Efisiensi Air". DKI Jakarta.

4. Putra, Teguh Permana. (2018). "Perancangan dan Pemanfaatan Penampung Air Hujan Skala Unit Rumah di Perumahan Alam Sinar Sari Dramaga". Institut Pertanian Bogor: Bogor.
5. Taufani, Aditya Riski, Puji Utomo, Taufiq Ilham Maulana, Musofa. "Teknologi Pemanen Kabut (Fog Harvesting) sebagai Solusi Mengatasi Masalah Kekeringan pada Dataran Tinggi”. Universitas Gadjah Mada: Yogyakarta.

6. Diakses pada tanggal 15 Mei 2019 dari http://www.kelair.bppt.go.id/sitpapdg/P atek/Spah/spah.html.

7. Diakses pada tanggal 13 Mei 2019 dari https://www.bmkg.go.id/iklim/prakiraanmusim.bmkg? $\mathrm{p}=11004 \&$ tag $=$ prakiraanmusim\&lang=ID 